
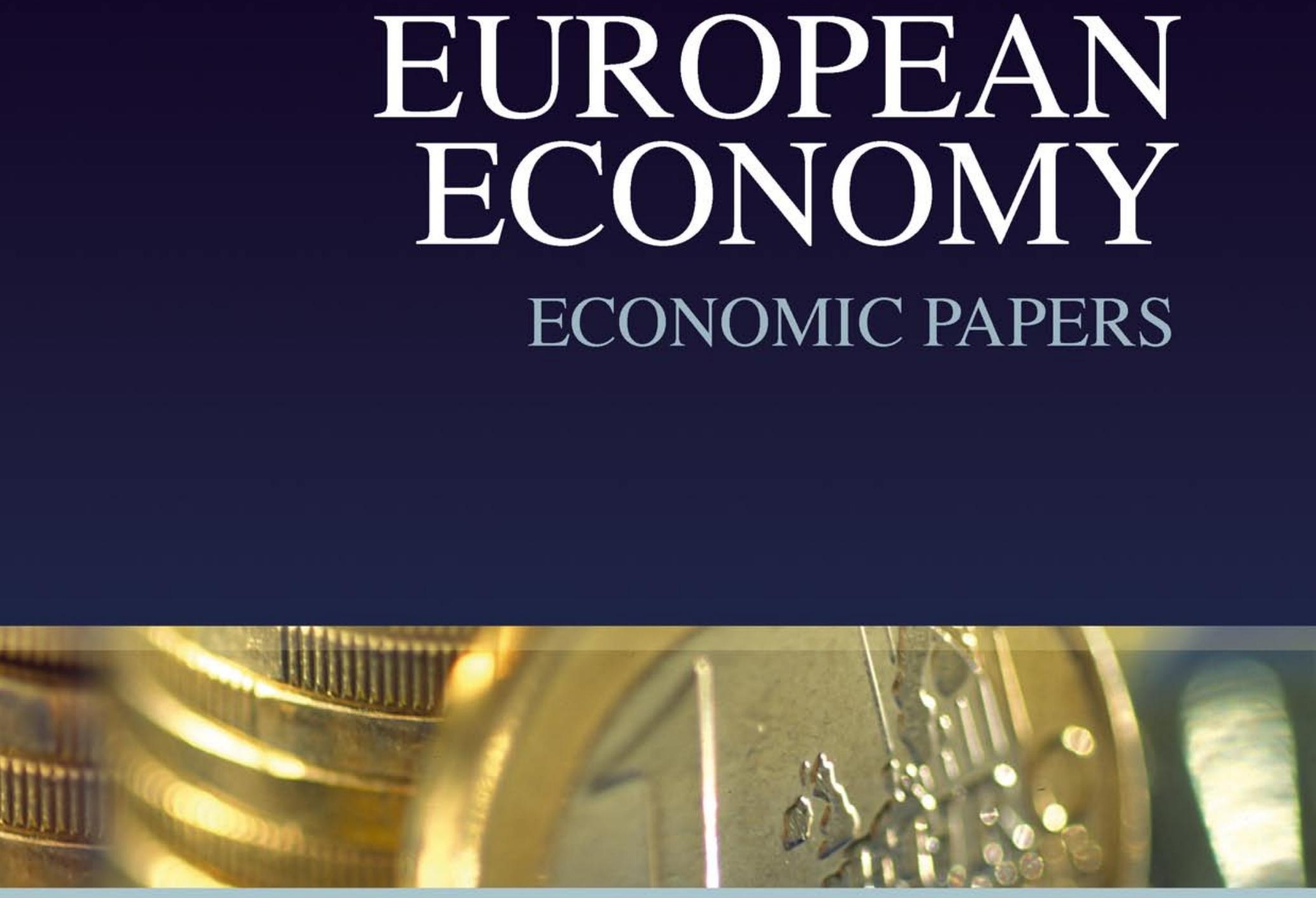

Number 294 - December 2007

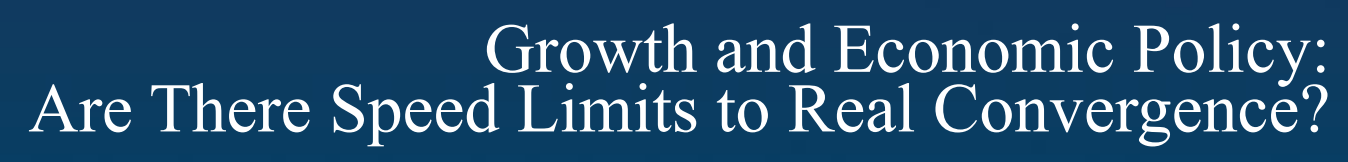

by István P. Székely and Max Watson Directorate-General for Economic and Financial Affairs 
Economic Papers are written by the Staff of the Directorate-General for Economic and Financial Affairs, or by experts working in association with them. The "Papers" are intended to increase awareness of the technical work being done by the staff and to seek comments and suggestions for further analyses. Views expressed represent exclusively the positions of the author and do not necessarily correspond to those of the European Commission. Comments and enquiries should be addressed to the:

\section{European Commission}

Directorate-General for Economic and Financial Affairs

Publications

BU-1

B - 1049 Brussels, Belgium 


\title{
Growth and Economic Policy:
}

\section{Are There Speed Limits to Real Convergence?}

\author{
István P. Székely and Max Watson ${ }^{1}$
}

\begin{abstract}
:
Real convergence in the recently acceded EU member states (RAMS) is taking place in a new environment, with important implications for convergence and vulnerabilities. Financial liberalization can increase temporary imbalances, while financial integration provides the necessary external finance to support the larger current account deficits involved. Thus, periods during which relative prices are distorted and resources are not reallocated to reach a new equilibrium can be lengthened. When prices are sticky, the exchange rate regime matters in the short run: a fixed exchange rate regime generates a larger current account deficit than a flexible exchange rate regime. That is, the extent of vulnerability to adjustment risk will depend on several factors, and trade-offs between these, including price stickiness, the extent of unhedged balance sheet exposures, and the degree of nominal flexibility afforded by the exchange rate regime. Financial liberalization and integration may also lead to sizable changes in the composition of final demand, and through this, considerable movements in the equilibrium real exchange rate. It may therefore be a challenging task for policymakers to achieve fast and steady nominal convergence in certain phases of convergence in this new environment. The paper discusses the challenges policymakers in RAMS face and the policies that can make the convergence process faster and smoother.
\end{abstract}

Keywords: real and financial convergence, financial integration, recently acceded EU member states.

JEL Classification: F43, E61, E44, D58

\footnotetext{
${ }^{1}$ Paper presented at the ECB Economic Conference on Central, Eastern and South-Eastern Europe, Frankfurt, 1-2 October, 2007. The authors are advisors at the European Commission, DG ECFIN. István P. Székely is on leave from the IMF, and is on the faculty of Corvinus University, Budapest. Max Watson is a Fellow of Wolfson College, Oxford. Views expressed are those of the authors and do not necessarily represent the views of DG ECFIN or the IMF. The authors wish to thank colleagues in DG ECFIN, and notably Julia Lendvai and Werner Roeger, for their great assistance in developing the material on which this paper is based.
} 


\section{INTRODUCTION}

The concept of speed limits to real convergence can be interpreted in two different ways. It can mean factors that limit or enhance potential growth in the recently acceded EU member states (RAMS) - in other words, speed limits to the potential pace of real convergence. But it can also mean factors that limit adjustment capacity and/or create market imperfections and rigidities, that is, speed limits due to vulnerabilities. Both are important and will be dealt with in this paper.

Regarding the former, recent research findings offer empirical evidence on the role of several non-traditional growth factors that are of particular importance in RAMS. These include the quality of institutions, the size and efficiency of government, and the development of the financial sector and financial integration. ${ }^{2}$

More attention to nontraditional growth factors reflects the fact that real convergence in RAMS is taking place in a new environment. The differences from previous convergence episodes are attributable to several factors, including financial integration, globalization, and European integration. RAMS also have important characteristics that are different from those of previously converging economies, such as the level of education or cross-border mobility of labor force.

\section{These differences in environment and characteristics also have important} implications for the speed limits due to vulnerabilities. On the one hand, financial liberalization - which provides a historically unique opportunity to use foreign savings to accelerate real convergence - can also increase the amplitude of certain cyclical elements, while financial integration, in large part due to European integration, can provide the necessary external finance for the kind of current account deficits that these larger deviations may generate. That is, these factors may lengthen the periods during which relative prices are distorted and resources are not reallocated to reach a new equilibrium.

It may be a challenging task for policymakers to achieve fast and steady nominal convergence, a prerequisite for euro adoption, in certain phases of convergence in this new environment. Financial liberalization and integration may lead to sizable changes in the composition of final demand, and through this, considerable movements in the equilibrium real exchange rate. As policies also work rather differently in the new environment, some even argue that they are ineffective, policymakers may face a double challenge in this regard.

\footnotetext{
${ }^{2}$ Some of these factors might have played an equally important role in previous convergence episodes but received little attention.
} 


\section{THE CONVERGENCE PROCESS}

RAMS are catching up with the average income level in the $E U$, and with each other, at a relatively rapid pace. The pace of convergence has accelerated since the turn of the century when EU accession became a central scenario for business. At the same time the dispersion of per capita relative income within this group started to decline rapidly, that is, the convergence also gathered pace among RAMS themselves (Figure 1).

Catchup with Europe and convergenece among EU10 (Per capita GDP at 2000 market prices relative to EU27 average)

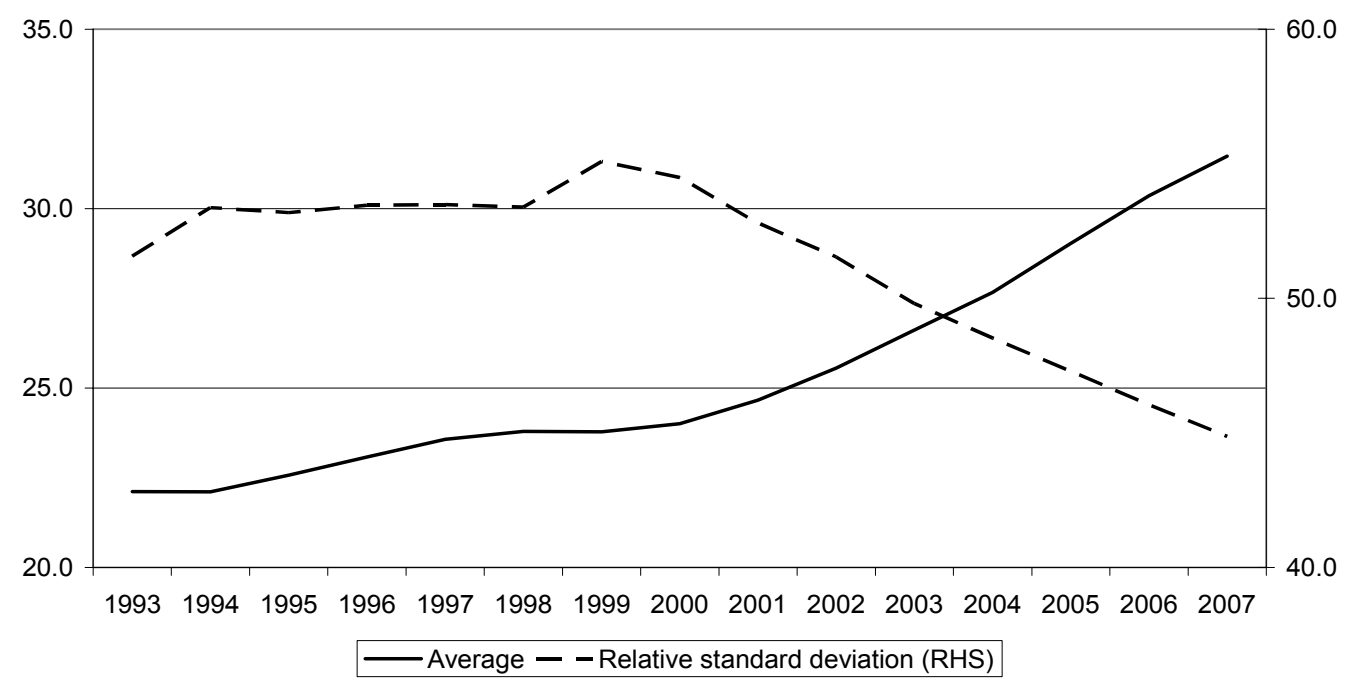

Both phenomena are mostly explained by the acceleration of convergence in the Baltic countries. These economies kept up with the fastest-growing emerging market economies, while the growth performance of the others has been, overall, more modest (Figure 2).

Catchup with Europe

(Per capita GDP at 2000 market prices relative to EU27 average)

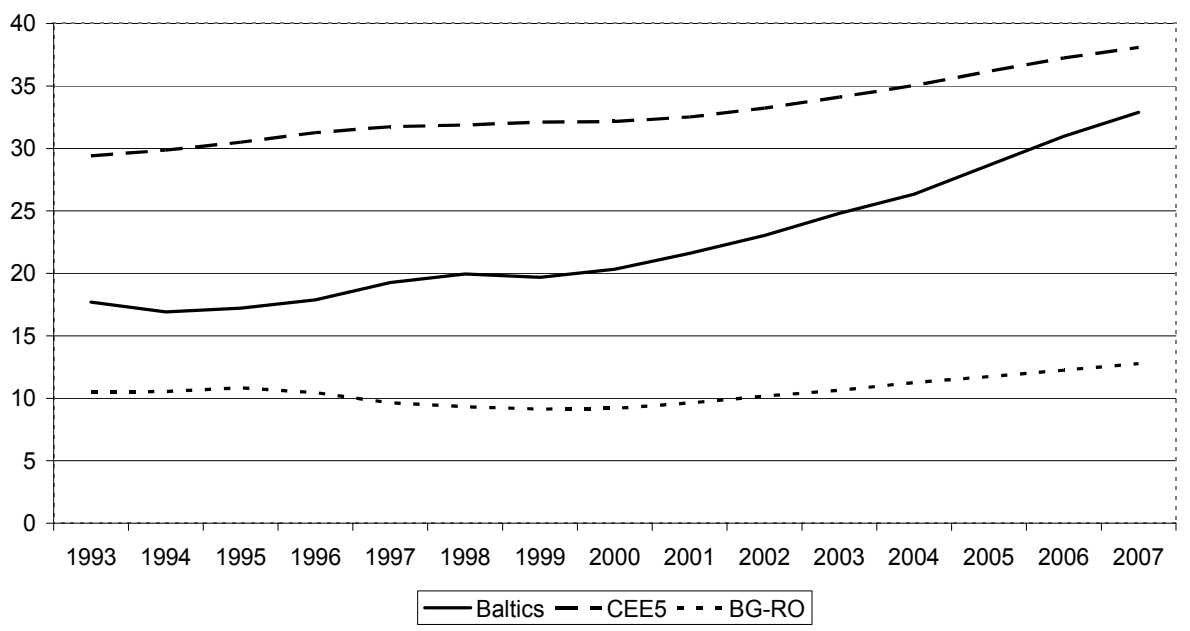


Exports product structures of most RAMS have also improved rapidly, indicating that these countries have a significant potential to absorb modern technology (Igan et al., 2007 and IMF, 2006). Given their relatively high educational achievements and the fact that their financial systems are well-developed, this is not surprising. Differences across countries in this regard are, however, also likely to be influenced by the quality of education and, more broadly, by their attractiveness for technology-transferring FDI (Figure 3).

Figure 3. RAMS: Educational attainment and change in export unit value, 1999-2004

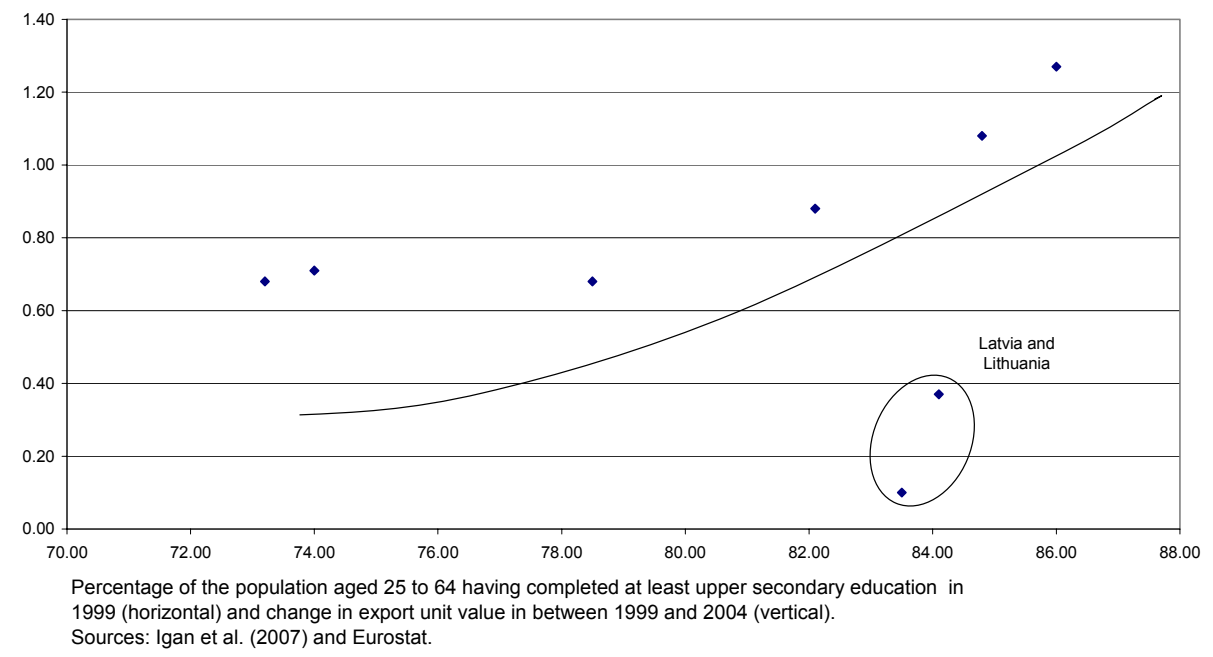

Caselli and Tenreyo (2005) call the attention to the importance of the initial production and employment structures in explaining the speed of convergence, especially in the early phases of convergence. Indeed, the share of agriculture, particularly if measured by employment, is rather different in RAMS, with Poland, among others having much higher shares of employment in agriculture (Figure 4 Chart on agricultural employment). The resulting scope for sectoral shifts can, in principle, be a source of rapid growth in the coming years in these countries, as was the case, e.g., in Spain. The issue, however, is broader than just agricultural employment even in Poland. The level of employment, and thus the potential in increasing labor input, is rather different across the RAMS, with the Baltic countries having relatively high employment levels by EU standards (Figure 5). 
Figure 4. RAMS: Share of Agricultural Employment in 2006

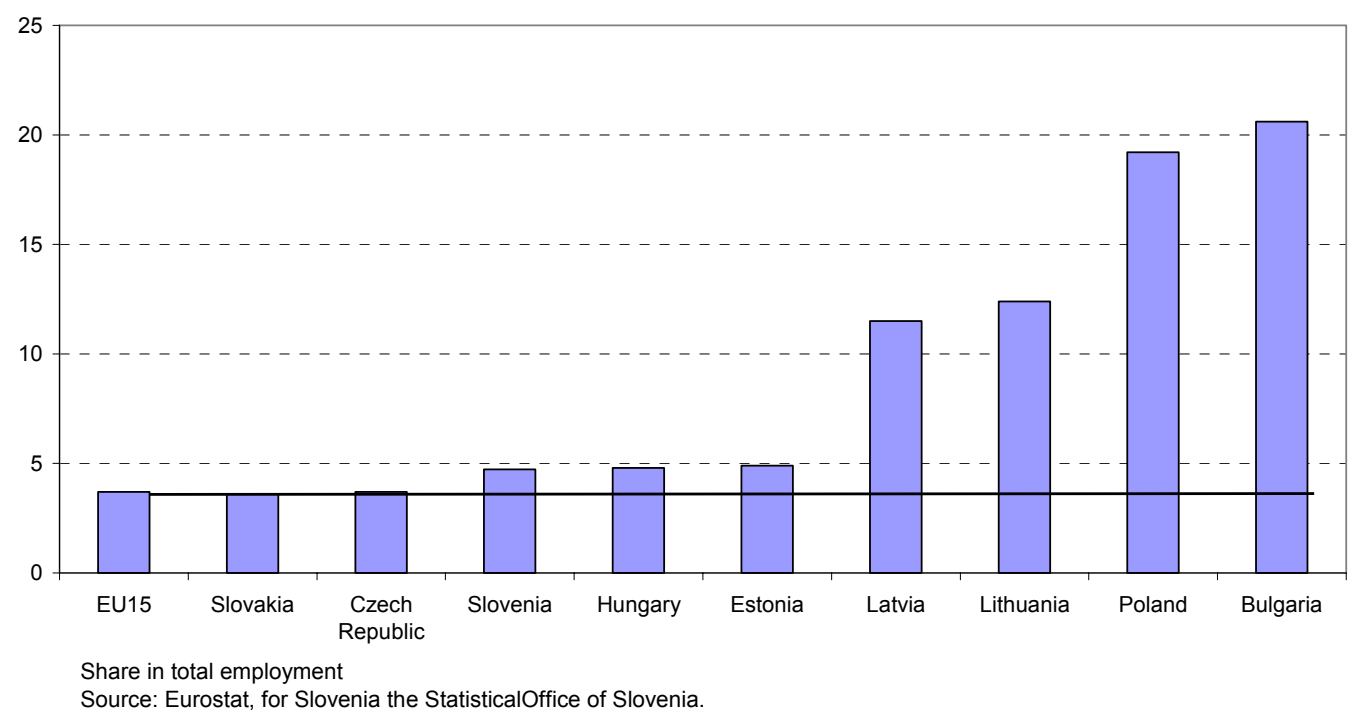

Figure 5. RAMS: Employment ratios in 2006

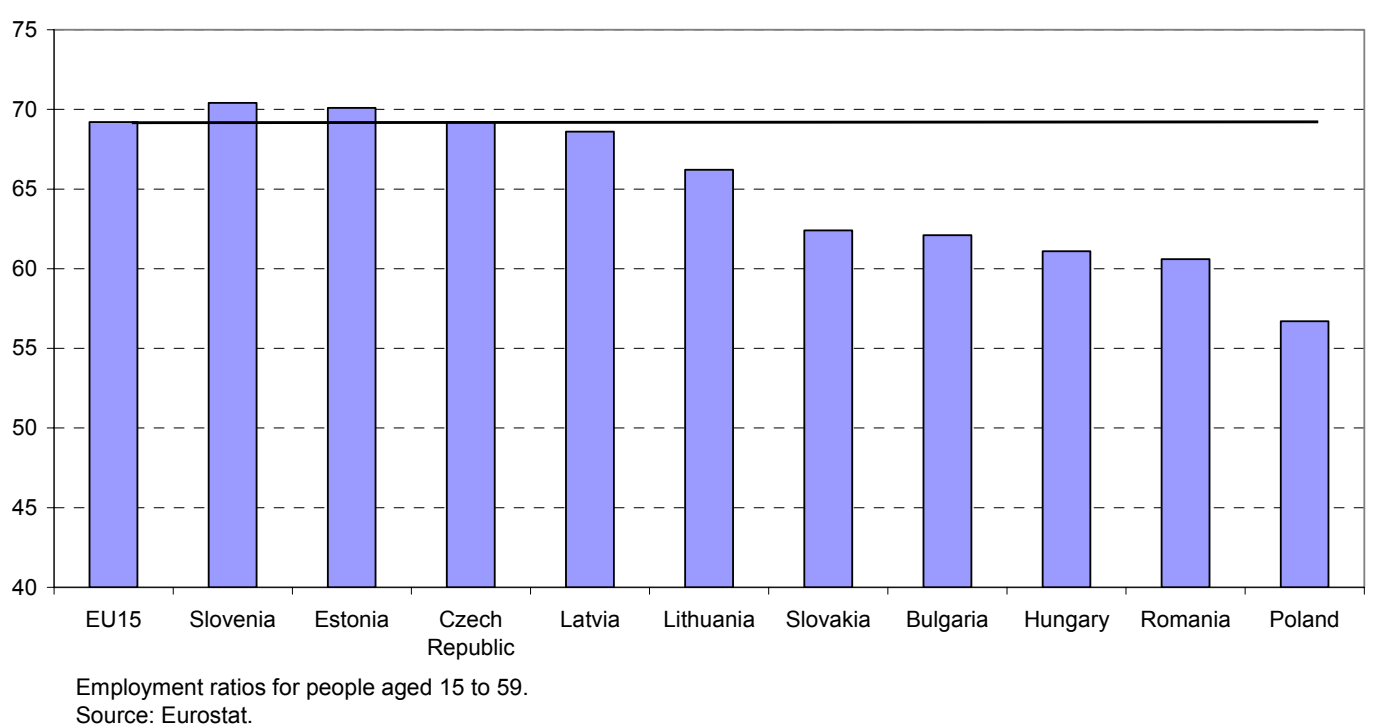

The process of convergence is associated with high current account deficits and rapid real appreciation in several RAMS. The recent experiences of the Baltic countries and Bulgaria are of particular importance in this regard, though the origins, and, thus, the longer- term implications for growth are likely to be rather different in these cases (Figures 6-8). The flip-side of real appreciation in RAMS with fix exchange rate regimes is somewhat higher inflation, though a periodic acceleration of inflation is not restricted to these countries (Figure 9, Inflation). 
Figure 6. RAMS: Current Account Deficit, 2004-06

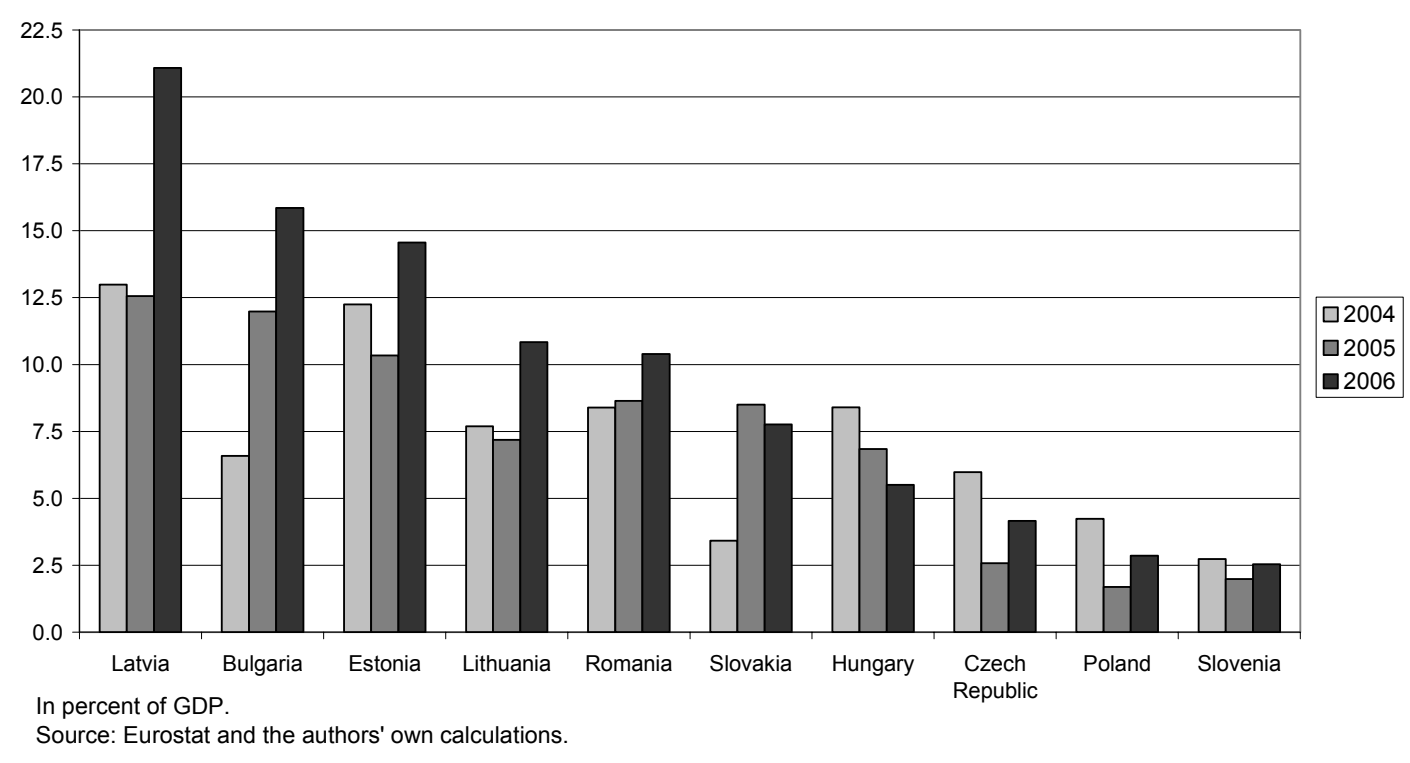

Figure 7. RAMS: Real Effective Exchange Rate Indices, 2006

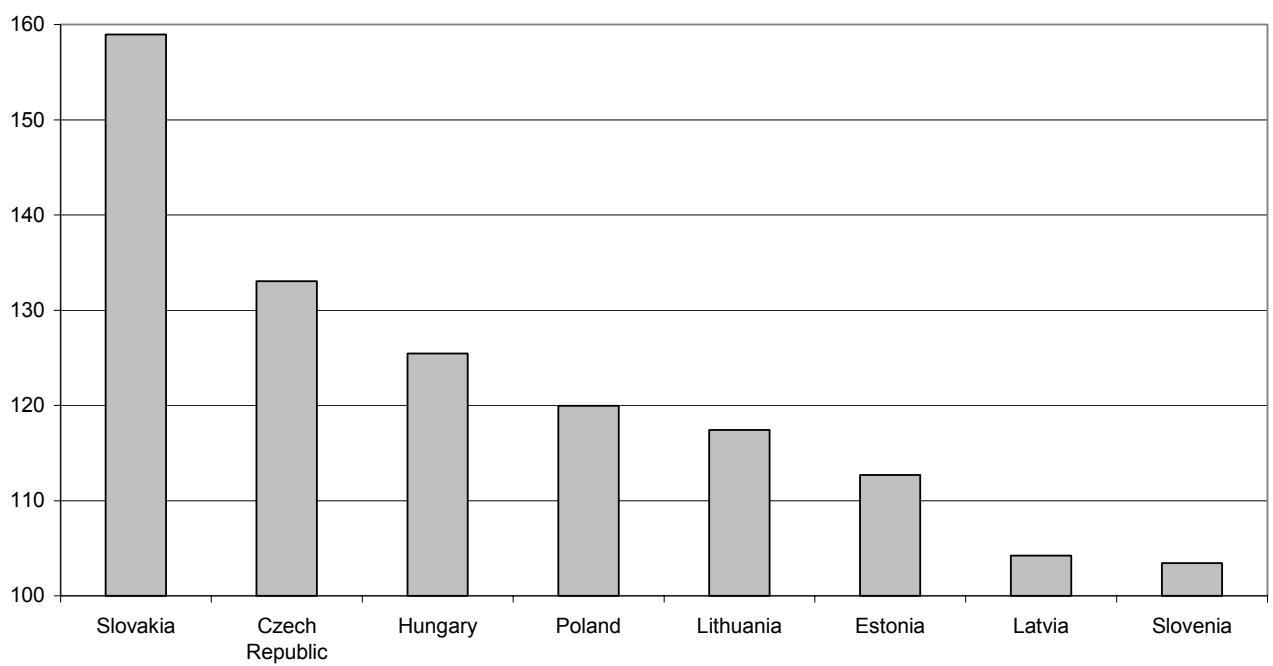

Based on CPI, 1999=100.

Source: Eurostat. 
Figure 8. RAMS: Change in Export Unit Value and Real Appreciation, 1999-2004

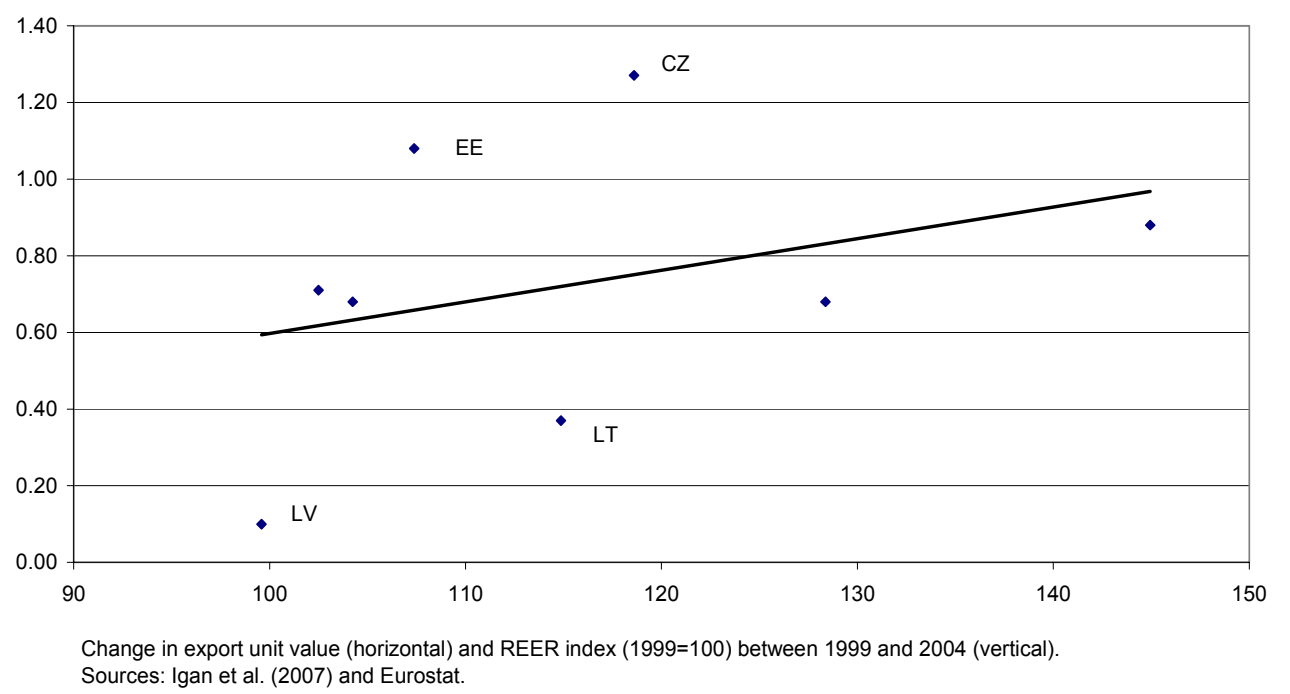

Figure 9. RAMS: Rate of Inflation, 2004-06

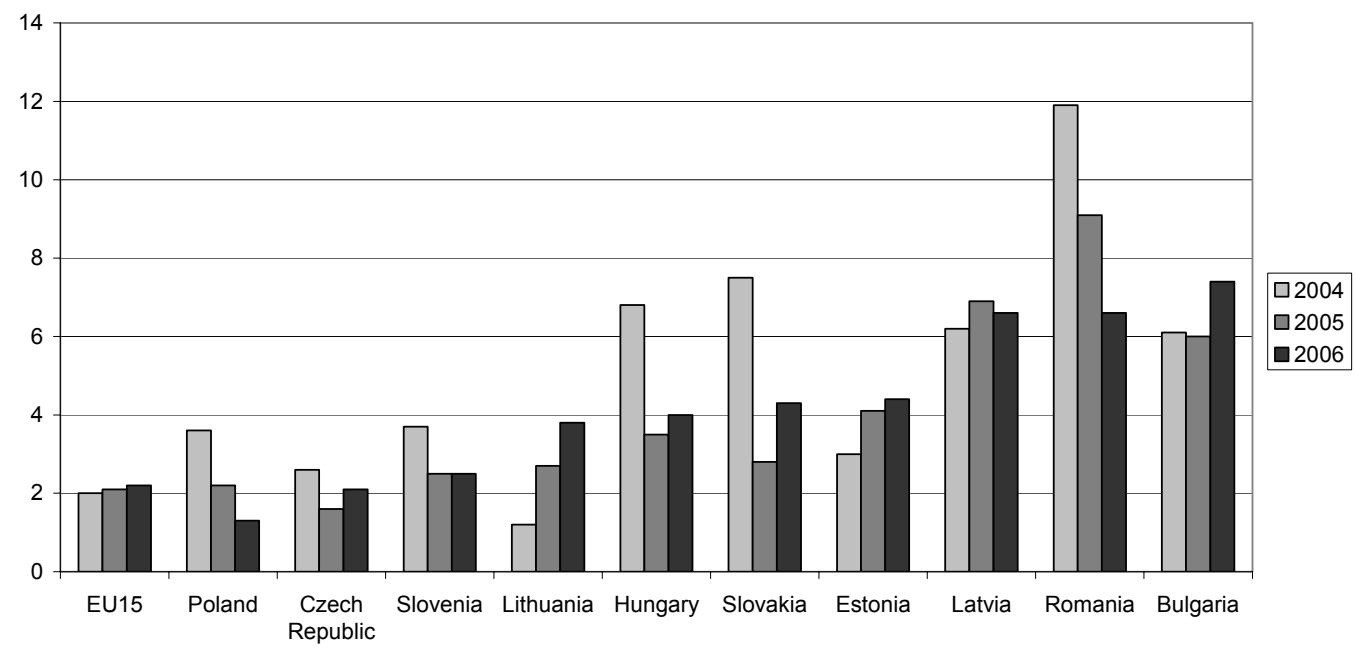

Harmonized indices of consumer prices $(2005=100)$ - Annual rate of change Source: Eurostat. 


\section{THEORETICAL FOUNDATIONS AND EMPIRICAL EVIDENCE}

Though findings are not always robust and/or theoretically well understood, there are several factors that are consistently found to influence growth performance in empirical studies. In what follows we shall review some of these findings and try to relate them to theoretical models in order to understand the channels through which, and the ways in which, they might influence catch-up potential in the RAMS. We shall also review how these factors might influence the adjustment to a new equilibrium and, through this, the variability of output and macroeconomic vulnerabilities. Of course, with perfect markets, fully informed agents, and flexible prices, theory would suggest no impact of such variability on potential growth. But these assumptions are not necessarily plausible for the RAMS (or other EU Member States). Thus major deviations from potential output create vulnerabilities - mostly, though not only, through large external gross financing requirements. Moreover, they also limit growth potential because of extended periods of distorted relative prices and slow responses to relative prices changes.

Other things equal, a lower initial income level seems to be associated with more rapid growth: lower-income countries, on average, do converge with higher-income countries. As the RAMS' income level is still significantly lower than that of the rest of the EU (Figure 1), this factor will potentially work in their favor, as it has done since the beginning of transition. The evidence for an interaction of this exogenous catch-up factor with policy determined factors, however, is much scarcer and more recent. Schadler et al. (2006) offer some evidence on the interaction with institutional quality and financial integration. These interactions are of particular importance to RAMS because European integration, by design, brings about major improvements in these areas. ${ }^{3}$

Aghion et al. (2006) offer a model that can establish a link between domestic savings and growth performance in a small open economy. This is an important, though long overdue, theoretical result. Even though it has been a widely-held view in economics that domestic savings matter for growth also in a small open economy, theory has long offered little support for this view. A crucial element of this link in the above model is the capacity of domestic banks to cofinance investments by foreign firms that bring local firms closer to the industry frontier. As monitoring is crucial to ensure efficient use of external financing by firms, the higher domestic savings are - the higher the domestic banks' capacity to cofinance - the higher foreign investment and, thus, the faster convergence to the efficiency frontier will be.

\footnotetext{
${ }^{3}$ Schooling, which influences a country‘s capacity to adopt new technologies (Howitt and Mayer-Foulkes, 2002), does not seem to have a strong explanatory power for the RAMS, perhaps because differences among them in this area are more qualitative than quantitative, as indicated in Figure 3.
} 
Schadler et al. (2006), however, find no evidence of this link to domestic savings for growth rates in the RAMS. Instead, they offer evidence suggesting that higher current account deficits - that is, more reliance on foreign savings — on average, speeds up convergence. ${ }^{4}$

Is this a contradiction, or a finding that reduces the relevance of this model? Not necessarily. The banking sector in most RAMS is dominated by foreign-owned banks that can bring in foreign financing at large scales and that have already developed the necessary capacity to efficiently monitor local firms. In fact, in the early phase, foreignowned banks mostly specialized in corporate financing and moved into the retail sector only more recently. So, there is a very plausible explanation for the fact that RAMS can easily substitute foreign for domestic savings ${ }^{5}$ and, on average, converge fast with the rest of the EU despite relatively low domestic savings (relative to, for example, South-East Asian countries, see Schadler et al., 2006). Large-scale FDI, and more broadly, openness to foreign ownership, is another factor that makes this channel less relevant. We shall take up this issue below.

In another seminal contribution, Aghion et al. (2005) present a model to explain how financial development can enhance the growth potential once it reaches a threshold level. ${ }^{6}$ This is an issue that has long been in the center of attention (Greenwood and Jovanovic, 1990, Levine, 1997, Demigrüç-Kunt and Levine, 2001). This model, however, is of particular interest to RAMS as it explicitly accounts for technological transfer and the role of financial development in this, a central mechanism for the convergence of RAMS. Their model predicts an acceleration of growth once financial intermediation (proxied by the private credit-to-GDP ratio) reaches a threshold level (at around 25 percent based on their estimates); and provide empirical evidence to support this prediction of their model.

\section{Though these results would suggest a strong relationship between financial} development and growth in the RAMS, empirical evidence is weak. Credit-to-GDP ratios in RAMS are above this threshold level and credit growth is well in excess of nominal GDP growth in most RAMS. Nonetheless, Schadler et al. (2006), for example, find no evidence that this factor is serving to enhance growth potential in these economies. $^{7}$

Again, this is not necessarily a contradiction. While increased access to credit is a

\footnotetext{
${ }^{4}$ Abiad et al. (2007) provide further empirical evidence and argue that Europe (RAMS) is different in this regard. They also make the important distinction between steady state growth and convergence, which might be essential to understand why previous studies for larger sets of low-middle-income countries found no evidence supporting this link (Kose et al., 2006), or found that capital tended to flow "uphill" (Prasad et al., 2006).

${ }^{5}$ For example, in Latvia, foreign borrowing by (mostly foreign-owned) domestic banks amounts to more than half of their total lending (to residents and non-residents), and over $2 / 3$ of their deposit base.

${ }^{6}$ Empirical investigations in Aghion et al. (2005) and Aghion et al. (2006) do not include RAMS as no reliable longrun data are available for these countries, simply because data for pre-transition periods are not very meaningful in this regard. The lack of data for a longer time period, of course, make it rather difficult to draw any conclusion from empirical work on the nature of the effects these development factors have on the growth or convergence potential of RAMS.

${ }^{7}$ It is, however, important to mention that they include variables that measure institutional quality, which might pick up some of the effects of the key mechanism involved in the models in Aghion et al. (2005) and Aghion et al. (2006), namely enterprise monitoring.
} 
positive development even if it is used for financing consumption or housing investment (since it allows households to optimize their consumption over a much longer time horizon) the contribution of credit expansion to potential growth is greatly dependent on how the increased credit is allocated. In the model of Aghion et al. (2006), this comes down to the assumption that credit finances innovation, or in that of Aghion et al. (2005) that finance is essential for the technology transfer - which clearly do not apply to credit that goes to nonproductive use, such as durables or housing. And indeed, the share of consumption and housing loans, is significant in the RAMS, albeit with important differences among countries (Figure 8). Thus, depending on the actual share of credit that finances innovation or technology transfer (more broadly, productive investment) in a given sample, one may or may not find financial development as a direct growth enhancing factor. ${ }^{8}$

FDI is another important factor that can enhance potential growth and convergence. It can directly finance innovation and/or transfer technology, and thus substitute for local innovation. ${ }^{9}$. RAMS have been benefiting from large FDI inflows since the beginning of transition, though to varying extent. Similarly to debt finance, the structure of FDI is key to understanding its implications for real convergence. FDI that finances or creates a real estate boom, in itself, is clearly not a factor that speeds up the convergence to the production frontier in the receiving country. ${ }^{10}$

Financial development and integration, however, can also increase vulnerabilities, especially if they take place in countries and periods that are characterized by major market imperfections. Improved access to credit by households, especially in countries with large pent-up demand for housing such as Latvia, can increase the demand for nontradable goods and shift resources in a dramatic fashion towards nonproductive uses even in the medium term. This, in turn, can lead to a sizable widening of the current account deficit and a considerable real appreciation - comparable in size or even larger than that generated by the B-S effect. Moreover, with sticky prices, the initial deterioration in the current account is significantly higher than with flexible prices, further increasing vulnerabilities (Box 1). This mechanism seems key to understanding recent developments in some RAMS with very large current account deficits and rapid asset price inflation, such as Latvia.

\footnotetext{
${ }^{8}$ For example, the share of loans to households and for real estate development in the increase in loans to the private sector (excluding financial institutions) amounted to 75 percent in the past year (12 months up to end Q1 2007) in Latvia.

${ }^{9}$ In fact, Aghion et al. (2006) directly estimate the implication of FDI for the impact of domestic savings on long-term growth and convergence and find that FDI makes this impact smaller, though still important. FDI is equally relevant to the model in Aghion et al. (2006).

${ }^{10}$ For example, in Latvia, 12 percent of cumulative FDI went into the real estate sector, and 37 percent into the financial system, which, at present, seems to finance mostly a real estate boom.
} 


\section{Box 1. Factors determining real exchange rate trends in converging economies}

The discussion on real exchange rate trends in converging economies has so far focused mostly on the possible size of the Balassa-Samuelson (B-S) effect. The general consensus is that this effect is modest (on average, 1-2 percent annually) (e.g., Kovács, 2002). More broadly, sectoral data for EU15 countries suggest that even in the euro area (a single market with a common currency), there are several uncertainties surrounding the very basic assumptions underlying the B-S framework, most importantly the one price assumption for tradable goods (Carsten and Ruscher, 2007). Moreover, recent movements in the real exchange rates of some of the converging economies have been much more dramatic than the estimated extent of the B-S effects, and real appreciation occurred even when TFP growth was mostly generated in nontradable sectors (e.g., Latvia).

\section{Recent research in the European Commission, however, provides important insight} into alternative mechanisms that might be equally important in determining real exchange rate trends in RAMS. They may also help better understand the recent experience of RAMS that witnessed rapid real appreciation, way beyond the possible extent of the B-S effect. Results of stochastic dynamic general equilibrium model-based simulations (Lendvai, 2007) seem to suggest that financial integration, most importantly increased access for households to credit, can be one such important factor. These results show that removing credit constraint on households, while leaving TFP growth unchanged both in tradable and nontradable sectors, leads to a persistent real appreciation and a widening of the current account deficit in the medium-run - just like in the case of the B-S effect. The long run implications are, however, markedly different from those of the B-S effect. The real exchange rate appreciates only temporarily, in the long-run it depreciates slightly (relative to the baseline) to generate the current account surplus necessary to service the higher net external debt accumulated in the first phase. That isunlike in the case of the B-S effect where the appreciation is permanent - the real exchange rate goes through major adjustments twice before a long-run equilibrium is reached again (Figure B1.1). ${ }^{11}$

\footnotetext{
${ }^{11}$ In discussing recent experiences of Portugal and Spain, Blanchard (2007) presents a model that can produce a similar outcome, but the shock in his model is a change in preferences, namely increased impatience (decrease in the discount factor). While we have evidence that supports an easing of the credit constraint on households in several RAMS, we have little to suggest a sudden change in preferences in any of the known episodes of rapid real exchange rate appreciation (and consequent widening of the current account deficit) in RAMS.
} 
Figure B1.1 Real exchange rate trends under different scenarios: Increased access by households to credit (upper panel) and TFP shock in the tradable sector (lower panel)

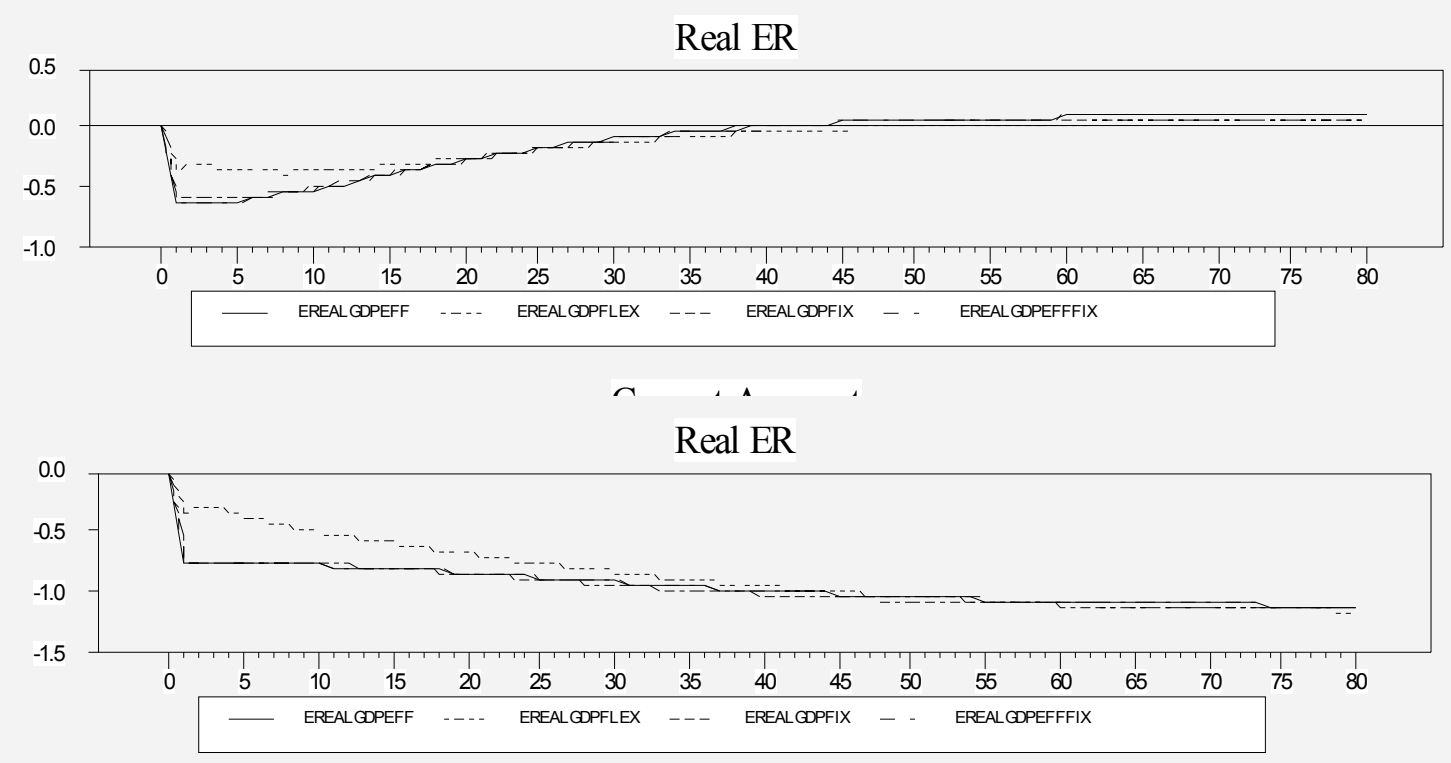

Source: Lendvai (2007).

Note: In the first simulation (upper panel), the loan-to-value ratio is increased by 10 percentage points for collateral constrained households, while in the second one (lower panel) there is a permanent 5 percent increase in the level of TFP in the tradable sectors. Both simulations are carried out with the same 2-country, 2-sector model in which 3 types of households are distinguished (Ricardian, collateral constrained, and liquidity constrained). Solid line: flexible exchange rate regime with sticky prices; dashed line: flexible exchange rate regime with fully flexible prices; -- - : fixed exchange rate regime with sticky prices; -- - --: fixed exchange rate regime with fully flexible prices. $\mathrm{T}=$ related to Traded goods sector, $\mathrm{NT}=$ related to Non-Traded goods sector.

\section{These results also shed some lights on the vulnerabilities rapid financial} development and integration can create in RAMS. As one would expect, when prices are sticky, the exchange rate regime matters in the short run: a fixed exchange rate regime generates a larger current account deficit (relative to the baseline) than a flexible exchange rate regime. That is, the extent of vulnerability to adjustment risk will depend on several factors, and trade-offs between these. These factors include the stickiness of prices, the extent of unhedged balance sheet exposures, and the degree of nominal flexibility afforded by the exchange rate regime. 
Figure B1.2 Current account developments following an increase in the access of collateral constrained households to credit.

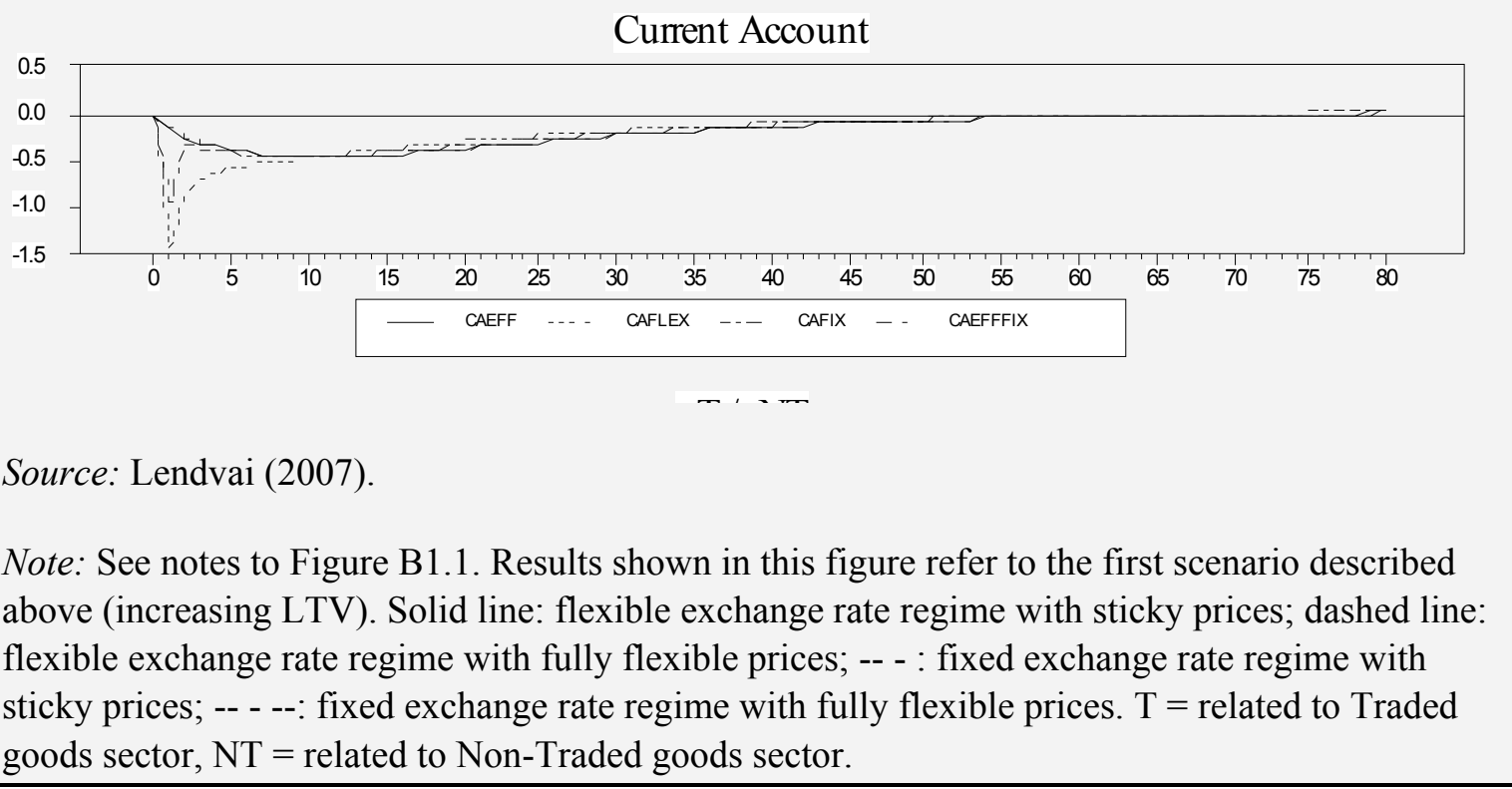

These findings offer a useful frame of reference for exploring some aspects of economic developments and policy challenges in the converging $E U$ economies. Notably, the two shocks illustrated here may be hard to distinguish initially, so policymakers may face a diagnostic problem. Meanwhile, the adjustment challenge facing the economy will be very different under these alternative scenarios. Under the 'household collateral shock', quite a significant corrective depreciation could be needed over the medium term: how smoothly this is achieved will depend on rigidities in the economy and on the capacity to switch resources and restart strong productivity growth at that stage. The implications for policy of this diagnostic uncertainty and potential adjustment challenge are explored in more detail below.

\section{It is, however, important to note that the distinction between investment in} productive and non-productive uses is not necessarily the same as the one between investments in tradable and non-tradable sectors. The overall productivity of an economy, and its long-term competitiveness, is not only a function of productivity in the tradable sectors - an issue that received considerable attention recently in Europe - but also the productivity of the non-tradable private sector, and that of the government sector. As Blanchard (2006) shows, higher productivity in non-tradable sectors can enhance the competitiveness of producers in tradable sectors in the same way as productivity increase in the tradable sectors does, by keeping wages down in tradable sectors. 
In fact, as he argues, for many PAMS - and we would add RAMS - it is much easer to implement reforms that enhances productivity growth in non-tradable sectors than attract more investment in high tech sectors. ${ }^{12}$

\section{Moreover, regarding RAMS, it is also important to keep in mind that the share of foreign ownership in tradable sectors, particularly in export sectors is rather high.}

That is, production technologies and managerial practices in a considerable part of the tradable sector are likely to be close to the efficiency frontier. In fact, many producers in tradable sectors are fully integrated into the global production networks of their parent companies. Rapid improvements of export product structure and export unit values in several RAMS, such as Hungary, Czech Republic, reflect this fact (IMF, 2006). In a way, the catching up is near full in these parts of the economies of RAMS. While this is a very positive development, this also means that productivity growth in RAMS in these sectors will be driven by developments at the frontier and, thus, will be similar to that in the rest of the EU. The catching up potential is thus related to the increase of the relative size of this part of the economies of RAMS. However, as evidence in Schadler et al. (2006) suggests, this is limited in most RAMS, most likely because of the relative lack of highly skilled labor, and institutional weaknesses that limit the capacity to rapidly reallocate resources. Looking forward, increasing the supply of highly skilled labor will take time and will require major improvements in the educational systems of RAMS, mostly in their higher education. While this is a crucial area for structural policies, private sector involvement is critical to improve allocative efficiency and ensure incentive compatibility.

The size of the government is found by some to influence growth performance, also in RAMS (e.g., Barro, 1991, or more recently Aslund and Jenish, 2005, and for RAMS, Schadler et al. 2006). A large government may reduce the growth potential because of the dead-weight loss stemming from collecting tax revenue; the larger the size the higher the loss through this channel. And in most RAMS, the government is similar in size to that in the rest if the EU euro area and significantly higher than in countries with similar income levels in other parts of the world, particularly in fast growing South-East Asian economies (table). The most damaging way of high tax intake is perhaps a high tax wedge on labor. Most RAMS score rater poorly in this regard (see, e.g., World Bank 2007) with tax wedges twice as high, or more, than those of their fast growing middle-income competitors. The Baltic countries, however, compare favorably in this regards, with an average size of government relative to GDP about $8 \frac{1}{2}$ percentage points lower than in the rest of RAMS. It is also important to point out that it is expenditure on social transfers and government consumption that explains most of the difference between RAMS and their competitors in this regard, expenditure items that are generally not found to enhance the growth potential directly (Barro, 1991). Moreover, if social transfer schemes are not well designed, which seems to be frequently the case in RAMS, it can significantly reduce labor market participation and labor supply.

\footnotetext{
12 This issue would also deserve more attention in the euro area, as it was lagging behind the US in the past decade mostly because of dismal performance in many non-tradable sectors.
} 
Though not only for this reason, employment ratios in RAMS, except the Czech Republic and the Baltic countries, are indeed rather low by international comparison (see, e.g. Schadler et al. 2006). ${ }^{13}$

\section{Nonetheless, size in itself is not necessarily the only, or even the main factor that determines how the government will influence the convergence potential of RAMS. ${ }^{14}$} More recent results by the World Bank (2007) call the attention to the quality of government (expenditure), and provide some evidence for transition economies that large government (above a certain threshold size) hinders potential growth only if government is inefficient. They provide important evidence for the efficiency of government spending in education and health care in transition economies and RAMS, and use the size of the government to approximate the impact of resource waste and deadweight cost. As results in Afonso et al. (2006) suggest, with the exception of Slovenia, the use of government size as an explanatory variable may not be a major distortion for RAMS (see Figure 7 in Afonso et al., 2006). ${ }^{15}$

\section{Macroeconomic policies can be very different, however, if an economy has rigidities} that may impede external adjustment. RAMS with fixed exchange rate regimes, currency boards or hard pegs, are indeed growing fast and have major imbalances. Schadler et al. (2006) find growth, and partly because of this current account deficit, above equilibrium in some of the Baltic countries. Rapid nominal convergences on interest rates and high inflation are apparent in this group of countries, producing low, in many cases negative real interest rate, which in turn thought to lead to a consumption boom (financed by credit) and a shift in investments towards nontradable sectors. While these phenomena are apparently present in these countries, it is not clear whether they are exclusively or even in the first place related to the choice on the exchange rate regime. First, euroization is widespread in countries with fix exchange rate regime, more so than in other RAMS, therefore, the low or negative real interest rate on domestic currencydenominated instruments can have little impact on overall resource allocation. Second, as long as the UIP condition holds, the domestic real interest rate will be low in a country irrespective of the exchange rate regime if there is strong real appreciation. Finally, a fixed exchange rate arrangement, including the currency board, is not necessarily more credible than any other arrangement, thus the risk premium is not necessarily lower for "fixers". It may be lower if economic fundamentals are stronger and fiscal policy is on a

\footnotetext{
${ }^{13}$ This is another channel through which a large government can reduce the relative income level (though not necessarily the long-term growth rate).

${ }^{14}$ There is also a technical issue related to the size of the government in this regard. Productivity is rarely measured in the public sectors and, thus, it is typically imputed by statisticians. A quick look into the data suggests that assumptions on productivity growth in the public sector across EU/OECD countries are rather similar at around $0-1 / 2$ a year. If so, by design, a larger government (higher share of GDP produced in the public sector) in a country than in another one results in lower growth even if the private sectors (and presumably the public ones as well) grow at the same rate in the two countries.

${ }^{15}$ Though it may slightly distort the parameter estimate for this variable if the equation is estimated for a wider set of countries. There is however, little support in Afonso et al (2006), for threshold size for government (35 percent of GDP) chosen in World Bank (2007). The finding by Schadler et al. (2006) that the size of government has a significant negative impact on growth also suggest that, in general, it is a relatively good proxy for resource waste in government.
} 
sustainable path. ${ }^{16}$ Therefore, it is not surprising that empirical studies (references) find no systematic effect of the exchange rate regime on growth performance.

Implications for vulnerabilities, however, might be different, particularly if a fixed exchange rate regime is combined with rigidities and imperfections. In an ideal economy, once the effects of a shock fade, the economy reaches its new equilibrium and resources will be reallocated accordingly. Therefore, there is no impact on long-term growth performance. For example, regarding the case of removing credit constraints discussed in Box 1, as households and other agents reach their desired net wealth positions and restructure their portfolios of financial and real assets and liabilities, the consumption and housing booms end and the economy finds a new equilibrium. With imperfect or missing markets and sticky prices, however, relative prices, including the relative prices of foreign exchange and labor, are persistent and, thus, remain distorted for a considerable period-increasing vulnerability and eventually reducing the convergence potential. Policies, thus, might matter.

\section{CHALLENGES FOR POLICY}

In this setting of financial integration and real convergence, the key challenges for policy are two-fold. First, an over-arching priority is to foster high potential growth over the medium term, thus raising the speed limits on economic activity. Second, policymakers must engage in suitable risk management, to avoid adjustment stresses that could set back the real convergence process. The framework illustrated above suggests important ways in which policy can contribute to both objectives.

Macroeconomic and structural policies, jointly, will have a key role to play in raising the ceiling on potential growth. A key concern will be to ensure that the scope for gains from financial integration is fully tapped. This requires a strong emphasis on actions to improve resource allocation. Credible macroeconomic policies can help ensure moderate real interest rates. Structural fiscal reforms to increase the efficiency (and thus reduce the size) of government and to rearrange priorities with a view to enhancing human resources, developing infrastructure, and avoiding distortions will enhance potential growth. Labor and product market policies can help shift resources toward new opportunities for productivity gains. Prudential policies can seek to counter capital market imperfections. Overall, the emphasis will be on maximizing potential gains from technology so as to raise total factor productivity, with financial integration playing a strong supportive role.

The risk management challenges facing policy-makers in containing vulnerabilities and enhancing adjustment capacity are complex. Nonetheless, it seems feasible to map these to challenges for the main branches of policy:

\footnotetext{
${ }^{16}$ In economies where the fix exchange rate regime was adopted in order to make political commitment to sound fiscal policies lasting (commitment device), like in the case of some of the Baltic countries, the exchange rate arrangement and higher credibility (and consequently lower risk premium) are likely to go hand in hand.
} 
- A first source of uncertainty and potential risk lies in the nature of the shocks that the economy is experiencing. As discussed above, an expansion driven by easier household borrowing constraints will ultimately require a correction of the real exchange rate to divert resources to debt service. During the correction phase, rigidities in the real and financial sectors may prove costly in terms of output foregone. In other words, the expansion will be an equilibrium process but may involve a testing adjustment phase. By contrast, where the drivers of growth are favorable shocks to productivity, then the need for later real depreciation will be lower and the adjustment challenges less. Initially, however, the symptoms of these shocks may be hard to distinguish, leaving policy-makers unclear about the magnitude of the challenges ahead.

- A second source of risk lies in distortions and incentive problems. These could cause a misallocation of resources, and move the economic expansion away from an efficient path. Distortions could stem from fiscal programs that affect financial markets (such as mortgage subsidies) as well as the real sector. Incentive issues may also be significant in the financial sector - for example, where moral hazard results from guarantees of deposit liabilities, or where private sector agents rely unduly on a commitment to exchange rate stability.

- Experience in advanced and emerging market economies points also to the risk that errors in fiscal policy could cause an unintended stimulus during the economic and financial upswing. Public revenues may benefit strongly from the tax-rich composition of activity during a financial boom, and there are risks that policy-makers may also underestimate the cyclical position of the economy. Such errors could lead to an unintended fiscal stimulus that impairs resource allocation - including by triggering unwarranted real appreciation. This could also complicate adjustment by reducing the stabilizing capacity of fiscal policy when a domestically driven boom loses steam.

These considerations suggest that policy-makers need to engage in a comprehensive risk-return strategy - enhancing resource allocation, and thus pushing out the frontier of potential growth, while also safeguarding the economy against adjustment stress.

There is clearly a strong potential for complementarity between the measures required to pursue these twin goals. Nevertheless, it will be valuable to analyze as far as possible the nature of the shocks affecting the economy and hence the potential demands on policy — and especially the adjustment challenges - that may lie ahead. Here, a promising analytical route is to simulate different combinations of shocks to the economy (for example, building on the DSGE approaches illustrated here). This can provide a basis to explore what underlying shocks and patterns of allocation are confirmed by observed trends in incomes, output, prices, the real exchange rate, the external balance and — with particular emphasis — sectoral productivity trends. 
In designing policies, moreover, country authorities need to take account of specifics in the EU integration and convergence context. On the one hand, the trade and integration opportunities of EU Accession and Membership, and the scope for institutional strengthening in line with the acquis communautaire, pose unique opportunities to raise the speed limits on growth. At the same time, this environment also fosters accelerated financial integration, thus raising the stakes for polices to the extent that it amplifies both opportunities and, in some ways, costs of policy failure. Moreover, policymakers in the converging economies have faced questions about the efficacy of economic instruments in managing financial risks in a rapidly integrating environment.

This concern about policy efficacy deserves careful exploration. There are certainly potential constraints on policy in this environment. Even where exchange rates are floating, there are limits on the autonomy of monetary policy, including through the prevalence of euro-denominated borrowing. Foreign-owned banks, which account for an overwhelming proportion of financial assets, have deep pockets in terms of capital and liquidity - meaning that prudential measures may have limited traction. And in a setting of ever deeper financial integration, credit controls are not likely to work well: they will tend to divert flows to cross-border or less supervised channels.

Clearly, policy is far from powerless. But effective risk management requires policymakers to internalize four cross-cutting features that are particularly pronounced in this policy environment:

- Policy interactions, as always, can be mutually reinforcing. But with large balance sheet risks they may not operate with the conventional sign. With unhedged foreign currency exposures, nominal depreciation can potentially be deflationary - affecting the desirable fiscal stance to flank devaluation. ${ }^{17}$

- Policy actions may have strong distributional effects: (1) depreciation in the presence of large currency exposures may compress the existing non-trade goods sector, which is unlikely to be hedged; (2) prudential tightening may particularly impact locally owned banks, and firms with less access to diversified funding, and both aspects of this may affect SMEs severely even in economies with relatively well-developed financial systems; and (3) monetary tightening and nominal appreciation may need to be sharp where the role of the domestic currency in financial intermediation is modest: the brunt of this will fall unevenly across firms. These distributional considerations underscore the case for fiscal measures to play a full role in the policy mix.

- Lying behind concerns about the "policy impotence" are two regime related issues: (1) there is an understandable reluctance to reactivate monetary policy, and potentially moderate unhedged borrowing, by ending hard-peg regimes; and (2)

17 This is also the case for real effective depreciation with an unchanged nominal rate, but the time-path of the balance sheet impact will be much more gradual. 
there is currently something of a vacuum as regards local systemic risks in large foreign-owned establishments - e.g., sector concentrations or intra-group funding vulnerabilities. In both cases, there are circumstances in which policy may need to "think outside the box" to regain full effectiveness. In other words, there are issues of regime design as well as policy calibration.

- Many measures are complementary, with mutually reinforcing benefits for adjustment and growth. This includes the scope for growth-oriented fiscal consolidation. But in some respects, policy-makers face tough trade-offs. This may be true of some measures needed to assure a risk-averse fiscal policy. Equally, the shift from a peg to a flexible rate, or even the very active use of interest rates under a flexible regime, may entail increased short-run volatility in the economy. This may be desirable to dampen excessive risk-taking, and even if costly may still be key to avoiding larger risks to growth in the future.

Therefore, it will be important to rely on quantified macroeconomic scenarios in exploring policy options. These models can also support the design of appropriate stresstests, which capture compound risks, and help explore the scope of policy interactions. They provide, too, some objective basis on which to discuss difficult inter-temporal tradeoffs of the kind highlighted above.

To provide a sound basis for policy-making, such scenarios need to build in explicitly a number of financial stability factors.

- The evidence from productivity growth about resource allocation during the boom, and the medium-term implications of different assumptions on this, including for swings in net foreign liabilities and the real exchange rate.

- The impact of balance sheet risks, where vulnerable exposures may lie in any sector of the economy - firms, households, banks, government, and the aggregate external balance sheet - and the interaction of sector exposures can be of key importance.

- Concerning the saving-investment balance of the private sector, the impact on this of rapid financial integration, credit growth and asset price increases: sensitivity analysis could explore how far the external current account might widen as a result, on varying assumptions about the fiscal stance.

- As regards real exchange rate adjustment, an exploration how adjustment through different channels - nominal exchange rate, wage and price level - may interact with rigidities, such as wage and price stickiness, and balance sheet exposures.

Together with the other issues discussed above, these considerations underscore that policy-makers face important analytical challenges. Gaining a better understanding of these issues is essential in the development of effective frameworks and measures. 


\section{CONCLUSION}

This paper has suggested some elements of a framework for thinking about "speed limits on growth" in the converging economies of the EU (RAMS). It has

distinguishing throughout between the challenges relating to potential growth and to adjustment risks. But in both respects it has laid particular emphasis on the interaction of financial integration with real economic convergence.

\section{The factors that may limit the convergence potential most in RAMS seem to be}

- Resource waste in public sector;

- Government policies that reduce labor force participation by distorting the relative price of labor; and

- Policies that promote shifting resources to nonproductive uses in the private sector, particularly when they are combined with market inefficiencies and sticky prices.

Though to a varying extent, Central and East European RAMS seem to suffer from all these problems, while Baltic RAMS face the latter as a major challenge.

Consequently, the most important ways of increasing the speed limit on growth potential in the former group is to enhance efficiency of government expenditure, most importantly on government consumption and social transfers, and use most of the efficiency gain not needed to restore fiscal sustainability for reducing the tax wedge on labor. The latter would also help with increasing employment. Since the housing boom in the Baltic countries - which in the short run boosts growth - is still ongoing, the possible negative impact on the convergence potential cannot yet be detected. Moreover, relatively small and efficient governments and increasing labor utilization will mask any negative effect by this factor. Nonetheless, it may turn out to be an important factor that could reduce an otherwise high growth potential and threaten macroeconomic stability.

Regarding policies, five main conclusions flow from this analysis:

- A key goal for policy frameworks should be to unlock the full potential offered by financial integration, including the interaction of cross-border flows with institutions that are well-placed for monitoring credit contracts.

- The nature of shocks to the economy is important. For example, higher productivity in traded goods, or an easing of collateral constraints on households will have rather different impact on growth prospects and will create different adjustment challenges. But, from the initial symptoms, it may be hard to discern which shocks are actually occurring.

- This argues for a comprehensive approach to policy management. One that aims to foster strong potential growth, to contain vulnerability risks, and to enhance adjustment capacity. In such a strategy, measures that promote higher productivity and address rigidities and distortions will take centre stage. 
- Policy is far from powerless to influence these outcomes. But the specifics of the EU convergence setting mean that particular attention is merited to the direction of policy interactions; the sectoral impact of measures; the design of policy regimes; and the inter-temporal trade-offs that may face policy-makers.

- The need to evaluate policy options, and also to design realistic stress-tests, argues in favor of developing quantified macroeconomic scenarios. This is one of several areas in which deeper economic analysis can shed light on policy challenges and responses, and can help to articulate persuasive policy approaches. 


\section{REFERENCES}

ABiad, ABDul, DANiel LeIgh, AND AshoKa Mody (2007), "International finance and income convergence: Europe is different", IMF Working Paper 07/64, March 2007

Afonso, António, Ludger Schuknecht, And Vito Tanzi (2006), "Public Sector EFFICIENCY: EVIDENCE FOR NEW EU MEMBER STATES AND EMERGING MARKETS", ECB Working PAPER SERIES NO. 581, JANUARY 2006.

Aghion, Philippe, Philippe Bacchetta, And AbhiJit BanerJee (2004), "Financial development and the instability of open economies", NBER Working Paper 10246, January 2004.

Aghion, Philippe, Diego Comin, And Peter Howitt (2006), "When does domestic saving matter for economic growth?, draft, August 4, 2006.

Aghion, PhilipPe And Peter HowitT (2006), "Appropriate growth policy: a unifying framework" 2005 Joseph Schumpeter Lecture, Journal of the European Economic Association, Vol. 4, No. 2-3, pp. 269-314.

Aghion, Philippe, Peter HowitT, AND DAVID MAYER-Foulkes (2005),"The effect of financial development on convergence: Theory and evidence", Quarterly Journal of Economics 120 (February), 173-222.

Aghion, Philippe AND I. MARINescu (2006), "Cyclical Budgetary Policy and Economic Growth: What Do We Learn from OECD Panel Data?"

Aslund, ANDERS AND NAZGul, Jenish (2005), "The Eurasian growth paradox?", Peterson Institute for International Economics, Washington, DC.

BARRO, R. (1991), "Economic Growth in cross section of countries, Quarterly Journal of Economics 106 (2), 407-43.

BARro, R. (1997), “Determinants of economic growth: A cross-Country Empirical Study", MIT Press, Camridge, MA.

BARRO, R. and X. Sala-I-Martin (1992), "Convergence“, Journal of Political Economy 100 (2), 223-51.

BARro, R. and X. Sala-I-Martin (2004), Economic Growth, $2^{\text {nd }}$ edition, Cambridge, Massachusetts: MIT Press.

Blanchard, O. (2006), "Adjustment within the euro. The difficult case of Portugal", MIT Working Paper, forthcoming, Portuguese Economic Journal. .

Blanchard, O. (2007), "Current account deficits in rich countries", NBER Working Paper Series 12925.

BREZSKI, CARSTEN AND ERIC RUSCHER (2007), Differences in price and cost competitiveness across euro area member states, mimeo.

Caselli, F And S. Tenreyro (2005): Is Poland the next Spain? NBER Working Paper Series 11045.

DEmigrüÇ-Kunt, AsLi AND Ross Levine (2001), Financial Structure and Economic Growth: A cross-Country Comparison of Banks, Markets, and Development. Cambridge, Massachusetts: MIT Press.

GreENWOOD, JEREMY AND BOYAN JOVANOVIC (1990), "Financial development, growth, and the distribution of income", Journal of Political Economy 98 (October), 10761107. 
HowitT, Peter AND DAVID MAYER-FoulKes (2002), "R\&D implementation and stagnations: A Schumpeterian theory of convergence clubs", NBER Working Paper Series 9104.

Igan, Deniz, Stefania Fabrizio, And AshoKa Mody (2007), "The Dynamics of Product Quality and International Competitiveness ", IMF Working Paper 07/97, April 2007.

IMF (2006), Czech Republic, Republic of Estonia, Hungary, Republic of Latvia, Republic of Lithuania, Republic of Poland, Slovak republic, and Republic of SloveniaExport Structure and Credit Growth, IMF Country Report No. 06/414.

Kose, M. Ayhan, Eswar Prasad, Kenneth Rogoff, And Shang-Jin Wei (2006), Financial globalization: A reappraisal", IMF Working Paper No. 06/189.

KovÁCs, MiHÁLy ANDRÁs (ED) (2002), "On the estimated size of the Balassa-Samuelson effcet in five Central and Eastern European Countries", NBH Working Paper $2002 / 5$.

KRAJNYÁK, KoRNÉLIA AND JEROMIn ZETTELMEYER (1998), "Competitiveness in transition economies: What scope for real appreciation?" IMF Staff Papers 45(2), 309-362.

LENDVAI, JULIA (2007), Modeling real convergence, mimeo.

LEVINE, Ross (1997), "Financial development and economic growth: Views and Agenda", Journal of Economic Literature 35(June), 688-726.

Levine, Ross, Norman LoAyza, And ThOrsten BeCK (2000), "Financial intermediation and growth: Causality and causes", Journal of Monetary Economics 46(August), 31-77.

Prasad, Eswar, Raghuram Rajan, AND ARVind Subramanian (2006), "Patterns of international capital flows and their implications for economic development", paper presented at the symposium "The New Economic Geography", The Federal Reserve Bank of Kansas City, Jackson Hole, Wyoming, August 24-26, 2006.

Schadler, Susan, AshoKa Mody, Abdul Abiad, AND Daniel Leigh (2006), "Growth in the Central and Eastern European Countries of the European Union", IMF Occasional Paper 252, IMF: Washington, 2006.

WORLD BANK (2007), "Fiscal Policy and Economic Growth: Lessons for Eastern Europe and Central Asia, The World Bank: Washington DC, 2007. 